\title{
Pembuatan Bilik Tes Swab Covid-19 Untuk Puskesmas Gondomanan Yogyakarta
}

\author{
MhD. Lutfi Fadillah ${ }^{1)}$, Yusuf A Amrulloh ${ }^{2)}$, Almira Budiyanto ${ }^{3)}$, Atyanti Dyah Prabaswari ${ }^{4)}$, \\ Hari Purnomo ${ }^{5)}$
}

\author{
Teknik Elektro ${ }^{\mathbf{1 , 2 , 3}}$, Teknik Industri ${ }^{\mathbf{4}, 5)}$ \\ Universitas Islam Indonesia \\ Jl. Kaliurang Km 14.5, Sleman, Yogyakarta, Indonesia \\ Email: yusuf.amrulloh@uii.ac.id
}

\begin{abstract}
ABSTRAK
Tes swab merupakan standar baku penegakan diagnosis Covid-19. Pada tes ini, petugas medis melakukan pengambilan sampel dari area rongga antara hidung dan mulut bagian belakang. Proses pengambilan sampel ini idealnya dilakukan di laboratorium. Namun untuk mempercepat proses skrining, proses pengambilan sampel juga dilakukan di tempat umum. Proses pengambilan sampel swab bisa sangat beresiko karena mengingat pasien bisa bersin atau batuk dan menyebabkan droplet berterbaran di udara. Untuk itu diperlukan suatu ruangan yang mampu mencegah potensi penularan Covid-19 lewat droplet tersebut. Pada proyek ini, dirancang bilik tes swab Covid-19 untuk penggunaan di area terbuka. Bilik tes swab ini dirancang dengan ukuran panjang 1 meter, lebar 1 meter, dan tinggi 2.1 meter sesuai antropometri orang Indonesia. Bilik ini dibuat menggunakan rangka alumunium dan dinding kaca. Selanjutnya, area bagian dalam bilik tes swab didesain sebagai ruang bertekanan negatif untuk mengurangi resiko infeksi melalui transmisi udara. Untuk menciptakan ruangan bertekanan negatif digunakan kipas exhaust dengan kapasitas 180 CMH (cubic meter hour). Lebih lanjut, bilik tes swab juga dilengkapi dengan sistem monitoring tekanan udara, suhu,.dan kelembaban. Parameter suhu dan kelembaban udara dimonitor dengan sensor DHT22, sedangkan tekanan udara menggunakan sensor D6F-PH0505AD3. Data sensor tersebut dibaca dengan menggunakan mikrokontroler Arduino Uno. Mikrokontroler tersebut membaca data kedua sensor secara periodik dan menampilkan pada LCD yang diletakkan di luar bilik sampel. Sistem monitoring akan memberikan peringatan berupa indikator LED apabila nilai tekanan udara di bawah setting yang ditentukan. Dari hasil pengukuran diketahui nilai akurasi tekanan, suhu dan kelembaban udara adalah sebesar 93,06\%, 98,25\%, dan 91,02\%. Bilik sampel yang dibuat telah diimplementasikan di Puskesmas Gondomanan Yogyakarta.
\end{abstract}

Kata kunci: bilik tes swab, tekanan negatif, Covid-19, droplet

\begin{abstract}
Swab test is the gold standard for diagnosing Covid-19. In this test, the sample of material is taken from the nasopharyngeal area. Ideally, the swab test should be carried in the laboratory. However, to speed up the screening process, many tests were carried in the public facilities. The process of taking sample can be very risky as the subjects may accidently cough or sneeze during the sample collection and make the droplet spreading through air. Therefore, we need a container that can reduce the risk of cross infection due to the droplet. To address the problem, in this project we developed a booth for swab test. The booth was made from aluminum as its frame and glass as its wall. The size of the booth was 1 meter length, 1 meter wide, and 2,1 meters height following the Indonesian anthropometry. The booth was designed as a negative pressure room. We used an exhaust fan with the capacity of $180 \mathrm{CMH}$ (cubic meter hour). The fan was placed on the upper side of the booth to create the negative pressure inside the booth. The negative pressure was monitored using D6F-PH0505AD3 pressure sensor. The booth was also equipped with DHT22, a temperature and humidity sensor. These sensors were controlled using an Arduino Uno microcontroller board. The microcontroller read the pressure, temperature, and humidity data periodically. The data was then displayed on an LCD monitor. Whenever the pressure was lower than a predefined setting, the microcontroller activated the LED indicator.
\end{abstract}


From the testing, the pressure measurement achieved the accuracy of 93,06\% while the temperature and humidity achieved the accuracy of 98,25\% and 91,02\% respectively. The developed booth had been deployed at Gondomanan Health Centre, Yogyakarta.

Keyword: swab test booth, negative pressure Covid-19, droplet

\section{Pendahuluan}

Covid-19 merupakan penyakit pernafasan yang berkembang menjadi pandemi di seluruh dunia. Penyakit ini disebabkan oleh virus SARS-Cov2 yang dapat menyerang paru-paru, bisa menyebabkan gagal nafas, dan berujung pada kematian (Hairunisa \& Amalia, 2020). Covid-19 telah menginfeksi hampir 300 juta orang di seluruh dunia dimana empat juta di antaranya terjadi di Indonesia (Hairunisa \& Amalia, 2020). Namun, jumlah infeksi sesungguhnya diperkirakan jauh lebih besar dari data yang ada, mengingat jumlah tes yang dilakukan di negara-negara tertentu sangat terbatas dikarenakan fasilitas dan alat tes (World Health Organization, 2020).

Penegakan diagnosis Covid-19 bisa dilakukan melalui tiga metode (Gunardi, 2021). Metode yang pertama adalah tes PCR (polymerase chain reaction). Tes ini digunakan untuk mendeteksi keberadaan RNA (ribonucleic acid) dari virus SARS-Cov2. Materi genetis dari virus ini mampu dideteksi sebelum antibodi maupun gejala muncul pada subjek yang terinfeksi. Oleh karena itu, hasil tes ini mampu mengindikasikan apakah sesesorang terinfeksi SARS-Cov2 walaupun masih pada awal infeksi. Untuk melakukan tes PCR, tenaga medis akan mengambil sampel swab di area nasopharyngeal untuk selanjutnya dikirim ke laboratorium untuk di analisis. Tes ini mempunyai tingkat akurasi paling tinggi dibanding tes lainnya.

Metode yang kedua adalah lateral flow tests (LFT) yang hasilnya bisa didapatkan ditempat tes dilakukan. Metode yang juga disebut tes antigen ini mirip dengan tes PCR yaitu dengan mengambil sampel di daerah nasopharyngeal. Pada tes ini, sampel ditempatkan pada suatu material yang dilapisi antibodi yang bisa mengikat protein virus SARS-Cov2. Tes ini akan memberikan hasil berupa garis berwarna yang mengindikasikan adanya infeksi. Walaupun hasil tes LFT bisa diperoleh dengan cepat, akurasi dari metode ini lebih rendah dibandingkan tes PCR.

Metode yang ketiga adalah tes antibodi. Setiap orang yang pernah terinfeksi virus SARS-Cov2 akan mempunyai antibodi di dalam darahnya. Pada tes ini sampel darah akan diambil dari jari kemudian dicek antibodinya. Tes ini hanya bisa mendeteksi orang yang pernah terinfeksi dan tidak bisa mendeteksi orang yang sedang terinfeksi.

Di Indonesia, diagnosis Covid-19 banyak dilakukan dengan menggunakan tes PCR dan tes LFT. Pada saat pengambilan sampel, terjadi kontak fisik antara petugas medis dan pasien. Kontak fisik tersebut bisa menimbulkan infeksi silang yang membahayakan petugas medis. Untuk mengurangi resiko infeksi silang, pada projek ini dibuat sebuah bilik tes swab dengan mekanisme tekanan udara negatif. Udara yang keluar akan difilter Selain itu, bilik tes swab ini juga dirancang agar dengan mudah bisa dipindahkan.

\section{Tinjauan Pustaka}

Bilik tes swab merupakan tempat pengambilan sampel swab yang bisa digunakan ditempat umum. Dengan bilik ini, tenaga medis bisa melakukan pengumpulan sampel dengan lebih aman. Bilik tes swab telah digunakan di beberapa negara seperti India maupun Korea Selatan. Di Korea Selatan, bilik tes swab dikenal sebagai Walk-Through (WT) testing for COVID-19. Bilik tersebut dibuat dengan tujuan untuk menghindari kontak langsung antara petugas medis dengan pasien serta memastikan pasien yang akan diuji tidak terinfeksi oleh pasien yang diuji sebelumnya. Waktu keseluruhan proses pengujian mulai dari pendaftaran sampai pembayaran dapat diselesaikan dalam 20 menit. Walk-Through (WT) testing for COVID-19 dibuat dengan menggunakan konsep negative pressure room (NPR) yang umumnya digunakan pada ruangan isolasi agar udara di dalam tidak bocor 
keluar (Choi et al., 2020). Selain itu, tujuan dari digunakannya konsep ruangan bertekanan negatif juga untuk mengurangi risiko infeksi melalui transmisi udara di dalam ruangan. Untuk mempertahankan tekanan negatif, jumlah udara yang keluar harus lebih besar dari udara yang masuk (Kementerian Kesehatan, 2012).

Di Indonesia, Rumah Sakit Akademik (RSA) UGM telah meluncurkan bilik sampel serupa yang diberi nama GAMA Swab Sampling Chamber. GAMA merupakan bilik sampel Covid-19 untuk melakukan pengambilan uji swab orang yang terduga terpapar Covid-19. Hal tersebut dilatarbelakangi karena kekurangan APD (Alat Pelindung Diri). Bilik tes swab GAMA menggunakan konsep ruangan bertekanan positif di dalamnya. Posisi petugas medis berada di dalam ruangan dan pasien yang diperiksa berada di luar. Ruangan bertekanan positif dipilih agar jika di luar ada droplet atau kontaminan dari pasien yang ada diluar maka petugas yang sedang ada di dalam ruangan tetap akan terlindungi sehingga tidak diperlukan lagi memakai APD level tiga (Sarbani, 2020).

Dari dua bilik sampel tersebut, setiap bilik sampel mempunyai kelebihan dan kekurangannya masing-masing. Pada bilik tes swab Korea Selatan, pasien yang berada di dalam bilik diharuskan dalam posisi berdiri. Dengan model ini pengambilan sampel bisa dilakukan dengan cepat. Namun posisi berdiri membuat pengambilan sampel terkadang lebih susah. Lebih lanjut, untuk pasien yang berumur lanjut dan pasien anak, posisi berdiri dirasa akan kurang nyaman. Di sisi lain, bilik tes swab GAMA dirancang menggunakan konsep ruangan bertekanan positif. Ruangan bertekanan positif memiliki kekurangan yaitu apabila pasien yang sedang di periksa batuk maka droplet atau kontaminan akan langsung menyebar ke sekitarnya. Tentu saja hal tersebut akan berbahaya bagi orang yang sedang berada disekitar bilik sampel tersebut. Berbeda dengan bilik sampel bertekanan positif, pada bilik sampel bertekanan negatif apabila pasien batuk maka droplet atau kontaminan hanya menyebar di dalam bilik saja. Udara kemudian ditarik oleh kipas exhaust dan dilewatkan pada serangkaian filter udara untuk memastikan virus tidak ikut terbawa ke udara bebas.

Di ruangan medis, mikroorganisme berbahaya sangat mudah untuk berkembang biak. Untuk meminimalkan hal tersebut terjadi di ruangan medis, sebagai contoh ruang pengambilan sampel, diperlukan pengaturan suhu, kelembaban, tekanan udara, filtrasi dan ventilasi udara (Kementerian Kesehatan, 2012). Sistem monitoring parameter lingkungan seperti suhu, kelembaban, dan tekanan udara di dalam bilik tes swab akan sangat bermanfaat.

\section{A. Prinsip Ruang Bertekanan Negatif}

Ruangan bertekanan negatif untuk bilik tes swab diilustrasikan pada Gambar 1. Ketika exhaust fan menyala, udara akan ditarik keluar dari dalam ruangan tersebut. Hal ini menyebabkan tekanan udara di dalam ruangan menjadi lebih rendah dibandingkan di luar ruangan. Secara alami, udara diluar akan masuk melalui celah diantara pintu. Mekanisme ini menyebabkan arah aliran udara bersih dari luar ruangan ke dalam ruangan. Apabila ada kontaminasi di dalam ruangan, udara hanya keluar melalui jalur exhaust fan dimana telah dipasang serangkaian filter untuk membersihkan udara sebelum terlepas ke udara (HIPPII PUSAT, 2019). 


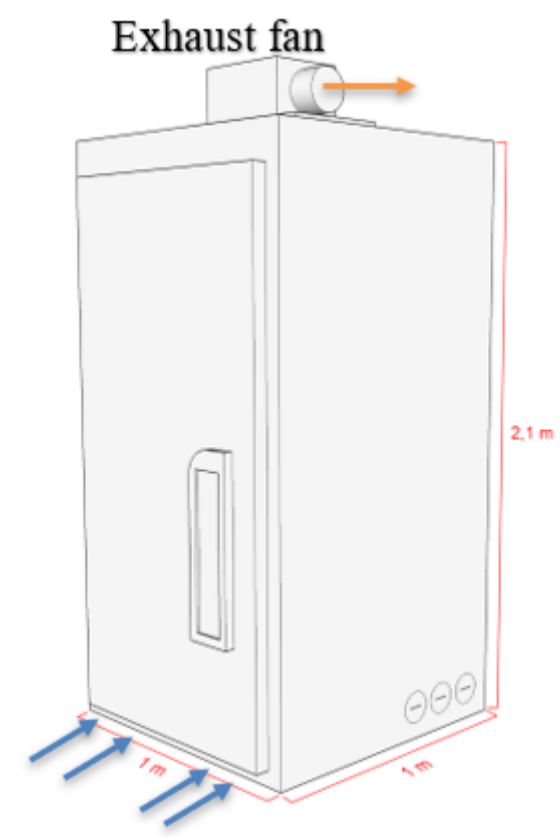

Gambar 1. Ilustrasi ruangan bertekanan negatif.

Kipas exhaust menarik udara keluar sehingga menciptakan tekanan negatif di dalam ruang bilik.

Untuk memastikan tekanan negatif ini terus terjadi, udara yang dipindahkan dari dalam ruangan harus lebih banyak dari yang masuk. Selain itu harus dipastikan tidak terjadi kebocoran sistem isolasi ruangan. Kebocoran udara dapat mengganggu bahkan dapat menghilangkan tekanan negatif ruangan. Standar minimal perbedaan tekanan udara di dalam dan di luar adalah 2,5 Pa dan memiliki nilai air change hour $(\mathrm{ACH})>12$ (Perdalin Kotapraja, 2017).

\section{B. Mekanisme Pengukuran Udara}

Badan Centers for Disease (CDC) Amerika Serikat menerbitkan pedoman mengenai pengendalian infeksi yang mencakup rekomendasi mengenai ruang isolasi tekanan negatif pada tahun 2003 [10]. Metode yang umum digunakan dalam pemantauan tekanan udara ialah uji asap atau tisu dan pemantauan elektronik. Tes asap atau tisu menggunakan asap atau kertas tisu dalam menilai tekanan ruangan. Asap atau tisu akan ditempatkan di dekat bagian bawah pintu dan jika asap atau tisu ditarik ke bawah pintu maka ruangan tersebut bertekanan negatif. Keuntungan tes tersebut yaitu hemat biaya dan mudah untuk dilakukan. Adapun kekurangan jenis tes ini adalah tidak dapat dilakukan secara terus menerus dan tidak bisa mengukur nilai tekanan udara.

Pemantauan secara kontinyu dapat dilakukan menggunakan perangkat elektronik. Keuntungan dari tes ini ialah pengujiannya dapat dilakukan terus menerus dan alarm akan memberi tahu petugas apabila ada perubahan tekanan yang tidak diinginkan. Kekurangan dari tes ini adalah perangkat yang di dalam ruangan dapat terkontaminasi, biaya pembelian dan pemasangan perangkat mahal, petugas harus dilatih agar paham dalam menggunakan dan mengkalibrasi perangkat (World Health Organization, 2007). Pengukuran tekanan udara secara realtime dapat menggunakan sensor elektronik. Salah satu sensor yang bisa digunakan adalah D6F-PH0505AD3. Sensor ini cukup praktis karena sensor ini dapat mengukur tekanan/aliran udara positif maupun negatif dari -50 Pa sampai 50 $\mathrm{Pa}$. Sistem kerja sensor ini dengan mendeteksi adanya perubahan aliran udara kemudian akan merubahnya menjadi tegangan listrik. Sensor tersebut mampu memberikan keluaran digital yang sangat akurat sesuai dengan tekanan yang diberikan (Mouser Electronics, 2021). 


\section{Mekanisme Pengukuran Suhu dan Kelembaban Ruangan}

Sistem monitoring suhu dan kelembaban diperlukan untuk mengetahui kondisi di dalam bilik tes swab. Hal ini bermanfaat untuk mengetahui apakah kondisi di dalam ruang cukup nyaman untuk subjek yang sedang diambil sampelnya. Secara umum, suhu yang direkomendasikan pada ruangan bertekanan negatif adalah sekitar $21^{\circ} \mathrm{C}$ sampai $24^{\circ} \mathrm{C}$ (Dwiatmo, 2020). Di rumah sakit, kondisi tersebut bisa dicapai dengan menggunakan air conditioner. Pada bilik swab, penambahan air conditioner akan menambah kompleksitas dan biaya. Lebih lanjut, virus SAR-Cov-2 penyebab mampu bertahan lebih lama di suhu yang dingin.

Selain suhu, kelembaban juga merupakan parameter penting. Pada kelembaban yang tinggi droplet pembawa SAR-Cov-2 lebih mudah jatuh, sehingga jarak transmisi melalui udara menjadi lebih pendek. Namun, kelembaban yang terlalu tinggi bisa menimbulkan ketidaknyamanan pada subjek yang diambil sampelnya. Untuk mengukur suhu dan kelembaban secara realtime bisa menggunakan sensor elektronik. Salah satu sensor yang bisa digunakan adalah DHT22. Sensor ini sangat praktis karena mampu mengukur suhu dari $-40^{\circ} \mathrm{C}$ sampai $80^{\circ} \mathrm{C}$ serta kelembaban relatif 0 sampai $100 \%$. Output data digital memudahkan pembacaan maupun pengiriman data jauh. Sensor DHT22 mampu mentransmisikan sinyal hasil pengukuran melewati kabel yang panjang hingga 20 meter, sehingga cocok untuk ditempatkan dimana saja (Saptadi, 2015).

\section{Sistem Alarm}

Sebagai unit pengendali, proyek ini menggunakan mikrokontroler board Arduino Uno. Mikrokontroler tersebut digunakan untuk membaca suhu dan kelembaban dari sensor DHT22 serta tekanan dari sensor D6F-PH0505AD3. Mikrokontroler juga bertugas untuk menampilkan data-data lingkungan tersebut ke LCD untuk dibaca pengguna. Lebih lanjut, agar pengguna tahu tekanan negatif bekerja, dibuat sistem alarm berupa sinyal LED. Pada sistem alarm ini, LED akan menyala apabila tekanan di bawah ambang batas yang ditentukan.

\section{Metodologi Penelitian}

Perancangan prototipe bilik sampel Covid-19 dan sistem monitornya dilakukan dalam 3 tahapan yaitu; i) Desain bilik sampel, ii) Desain sistem monitoring, dan iii) Pengujian dan analisis sistem:

\section{A. Desain Bilik Sampel}

\section{A.1.Bilik Sampel}

Desain bilik tes swab yang dibuat ditunjukkan Gambar 2 (Fadillah, 2020). Ukuran bilik dirancang berdasarkan data antropometri orang Indonesia yaitu meliputi tinggi badan, tinggi bahu, tinggi siku. Bilik swab Covid-19 berdimensi panjang 1 meter, lebar 1 meter dan tinggi 2,1 meter. Bilik tersebut dibuat menggunakan rangka aluminium, dengan lapisan bawahnya berupa tripleks melamin, sedang dindingnya menggunakan bahan kaca setebal $5 \mathrm{~mm}$. Kaca dan tripleks melamin dipilih karena mudah untuk dibersihkan dengan disinfektan. Bilik sampel ini juga dilengkapi dengan 4 buah roda agar bilik lebih mudah untuk dipindah-pindah. Pada bagian belakang bilik sampel juga disediakan dua buah lubang dengan diameter sebesar $25 \mathrm{~cm}$ untuk dudukan tangan diletakkan. 

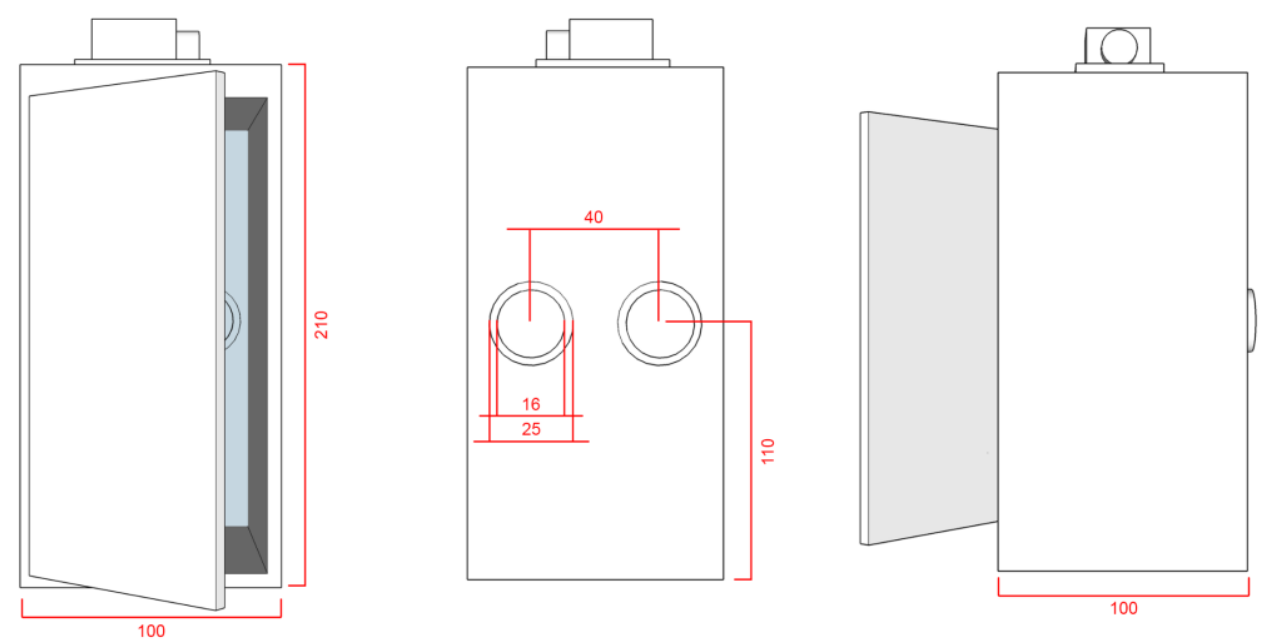

Gambar 2. Desain bilik tes swab Covid-19.

\section{A.2.Dudukan tangan}

Tenaga medis melakukan pengambilan sampel menggunakan akses berupa lubang yang diberi sarung tangan. Dengan adanya sarung tangan dan dinding kaca maka tenaga medis dan subjek terpisah secara fisik sehingga proses pengambilan sampel lebih aman. Sarung tangan ditempatkan secara kuat namun mudah untuk diganti dengan menggunakan dua buah dudukan. Dudukan tangan bilik sampel Covid-19 terbuat dari bahan aklirik tebal $5 \mathrm{~mm}$ berbentuk lingkaran yang berjumlah dua buah seperti ditunjukkan Gambar 3. Masing-masing dudukan tangan terdiri dari lingkaran berdiameter $31 \mathrm{~cm}$ dan di tengahnya terdapat sebuah lubang berdiameter $16 \mathrm{~cm}$. Pada dudukan tersebut dipasang 2 buah sarung tangan. Dudukan tangan dibuat dengan jarak $110 \mathrm{~cm}$ dari lantai dan jarak antar lubangnya sebesar $40 \mathrm{~cm}$. Ukuran ini digunakan untuk mempermudah petugas medis dalam pengambilan sampel pasien yang ada di dalam bilik swab.
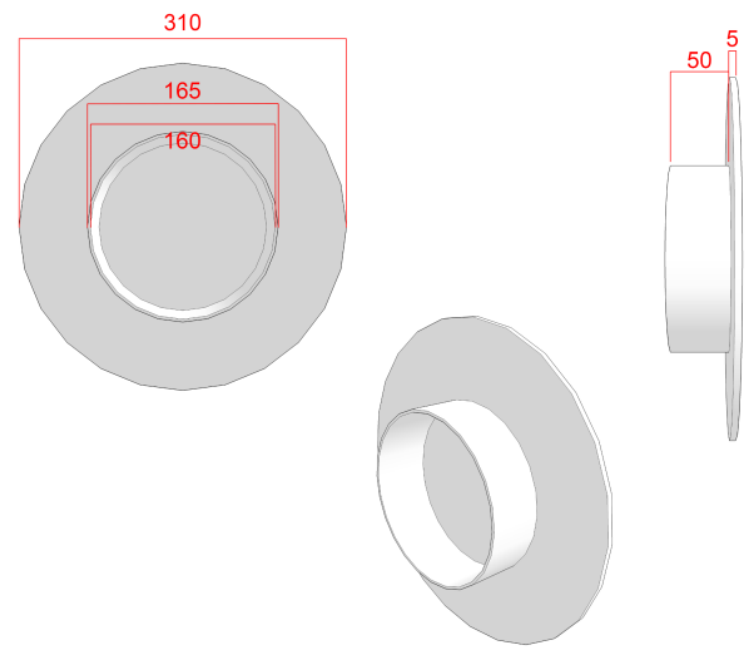

Gambar 3. Desain dudukan tangan pada bilik tes swab Covid-19. 


\section{B. Desain Sistem Monitoring}

\section{B.1. Desain Sistem Elektronika}

Komponen yang dibutuhkan dalam pembuatan sistem monitoring bilik sampel Covid-19 dapat dilihat pada Gambar 4 (Fadillah, 2020). Sistem monitoring bilik sampel Covid-19 dibagi menjadi 3 bagian yaitu sensor, mikrokontroler dan penampil. Bagian sensor terdiri dari sensor DHT22 untuk suhu dan kelembaban serta sensor tekanan D6F-PH0505AD3. Bagian kedua adalah board mikrokontroler Arduino Uno yang digunakan untuk membaca sensor dan menampilkan hasil ke bagian penampil yaitu LCD 2 baris 16 karakter. Selain itu terdapat LED untuk indikator tekanan udara.

Sensor D6F-PH0505AD3 dilengkapi dengan dua buah masukan, yaitu selang udara di dalam ruangan dan selang udara di luar ruangan. Dengan mekanisme tersebut perbedaan tekanan udara di dalam dan di luar ruangan bisa diukur.

Prinsip kerja dari sistem monitoring adalah secara periodik membaca data dari sensor untuk ditampilkan di LCD. Selain itu, sistem monitoring juga akan membandingkan pembacaan sensor tekanan dengan suatu nilai referensi yaitu 2,5 Pa. Apabila tekanan dibawah nilai tersebut, indikator LED akan dinyalakan.

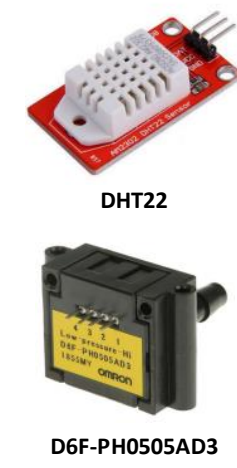

DGF $\mathrm{PHOSOS}$
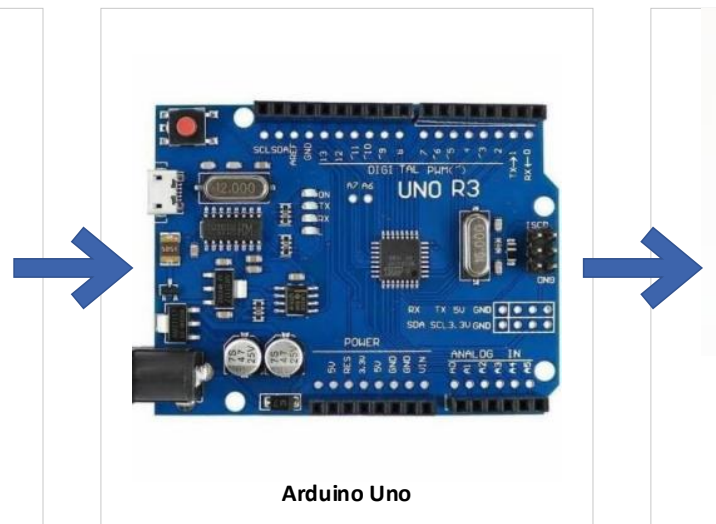

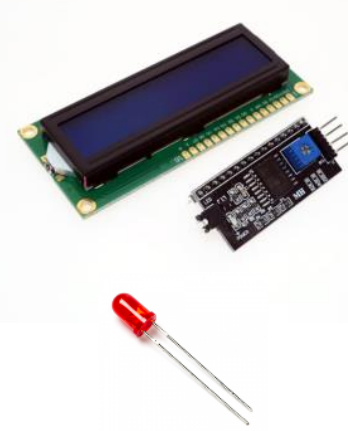

LCD \& LED

Gambar 4. Sistem elektronik yang digunakan untuk monitoring terdiri dari sensor DHT22 dan D6F-PH0505AD3, board mikrokontroler Arduino Uno, LED dan LCD yang dilengkapi unit komunikasi serial.

\section{Pengujian Sistem}

\section{C.1.Prosedur Pengukuran dan Kalibrasi Sensor}

Pengujian dan kalibrasi sensor dilakukan sebagai berikut. Pertama, output sensor DHT22 dibandingkan dengan alat ukur HTC V.02 Environment. Kemudian secara simultan, keduanya digunakan untuk mengambil data mulai dari jam 05.50 sampai 17.30 WIB. Perubahan suhu dan kelembaban dari pagi sampai sore dimanfaatkan dalam kalibrasi sensor DHT22 terhadap HTC V.02 Environment. Tabel 1 menunjukkan perbandingan pembacaan DHT22 dah HTC V.02 Environment.

Tabel 1. Perbandingan Pembacaan DHT22 dan HTC V.02 Environment

\begin{tabular}{lll}
\hline Perbandingan Pembacaan & DHT22 & HTC V.02 Environment \\
\hline Jangkauan pembacaan suhu & $-40^{\circ} \mathrm{C}$ sampai $+80^{\circ} \mathrm{C}$ & $-50^{\circ} \mathrm{C}$ sampai $+70^{\circ} \mathrm{C}$ \\
Jangkauan pembacaan kelembaban & $0 \%$ sampai $100 \% \mathrm{RH}$ & $10 \%$ sampai $99 \% \mathrm{RH}$ \\
Akurasi pembacaan suhu & $< \pm 0.5^{\circ} \mathrm{C}$ & $\pm 1^{\circ} \mathrm{C}$ \\
Akurasi pembacaan kelembaban & $\pm 2 \% \mathrm{RH}(\mathrm{Max} \pm 5 \% \mathrm{RH})$ & $\pm 5 \% \mathrm{RH}$ \\
Resolusi pembacaan suhu & $0.1^{\circ} \mathrm{C}$ & $0,1^{\circ} \mathrm{C}$ \\
Resolusi pembacaan kelembaban & $0.1 \% \mathrm{RH}$ & $1 \% \mathrm{RH}$ \\
\hline
\end{tabular}


Pada langkah selanjutnya, sensor D6F-PH0505AD3 dikalibrasi dengan menggunakan magnehelic pressure gauges. Masing-masing bagian sensor dan kalibrator dipasang selang dengan panjang kurang lebih $1 \mathrm{~m}$. Kemudian selang sensor dan kalibrator dimasukkan pada boks kalibrasi ukuran $30 \mathrm{~cm}$ x $30 \mathrm{~cm}$ x $50 \mathrm{~cm}$ yang dibuat dengan tutup atas tripleks. Pada boks kalibrasi terdapat lubang berukuran panjang $20 \mathrm{~cm}$ dan lebar $30 \mathrm{~cm}$. Untuk mendapatkan perbedaan tekanan udara, nantinya lubang akan dibuka perlahan dalam 7 titik yaitu $28 \mathrm{~Pa}, 24 \mathrm{~Pa}, 20 \mathrm{~Pa}, 16 \mathrm{~Pa}, 12 \mathrm{~Pa}, 8 \mathrm{~Pa}$, dan $4 \mathrm{~Pa}$. Pada masing-masing titik dilakukan pengambilan data selama 3 menit (180 data) dengan kondisi exhaust menyala (daya hisap exhaust $90 \mathrm{CMH}$ ). Perubahan tekanan udara yang disebabkan oleh ukuran lubang dimanfaatkan dalam kalibrasi sensor D6F-PH0505AD3 terhadap magnehelic pressure gauges.

Tabel 2. Perbandingan Pembacaan D6F-PH0505AD3 dan Magnehelic pressure Gauges

\begin{tabular}{lll}
\hline Perbandingan Pembacaan & D6F-PH0505AD3 & Magnehelic Pressure Gauges \\
\hline Jangkauan pembacaan & $-50 \mathrm{~Pa}$ sampai 50 Pa & $-30 \mathrm{~Pa}$ sampai 30 Pa \\
Akurasi pembacaan & $\pm 3 \% \mathrm{RD}$ & $\pm 2 \% \mathrm{FS}$ \\
Sensitivitas pembacaan & $\pm 0.2 \mathrm{~Pa}$ & $\pm 1 \mathrm{~Pa}$ \\
\hline
\end{tabular}

\section{Pengujian Sistem Monitoring}

Pengujian pertama dilakukan dengan membiarkan pintu boks kalibrasi tetap terbuka dan exhaust fan dalam kondisi mati. Pada kondisi tersebut akan dilakukan pengambilan data suhu, kelembaban dan tekanan udara selama 10 menit. Pengujian kedua dilakukan dengan tetap membiarkan pintu boks kalibrasi terbuka dan exhaust fan dinyalakan. Pada kondisi tersebut akan dilakukan pengambilan data suhu, kelembaban dan tekanan udara selama 10 menit.

Pengujian ketiga dilakukan dengan menutup pintu boks kalibrasi dan exhaust fan tidak dinyalakan. Pada kondisi tersebut akan dilakukan pengambilan data suhu, kelembaban, dan tekanan udara selama 10 menit. Pengujian keempat dilakukan dengan tetap membiarkan pintu boks kalibrasi tertutup namun exhaust fan dinyalakan. Pada kondisi tersebut akan dilakukan pengambilan data suhu, kelembaban, dan tekanan udara selama 10 menit.

\section{Hasil dan Pembahasan}

\section{A. Bilik Sampel}

Bilik sampel yang sudah jadi ditunjukkan pada Gambar 5. Bilik sampel ini dibuat dari material kaca dan lantai bilik terbuat dari tripleks. Bilik sampel berdimensi $100 \mathrm{~cm}$ x $100 \mathrm{~cm}$ x $210 \mathrm{~cm}$. Bilik sampel ini sudah dikirimkan dan digunakan di Puskesmas Gondomanan Yogyakarta.

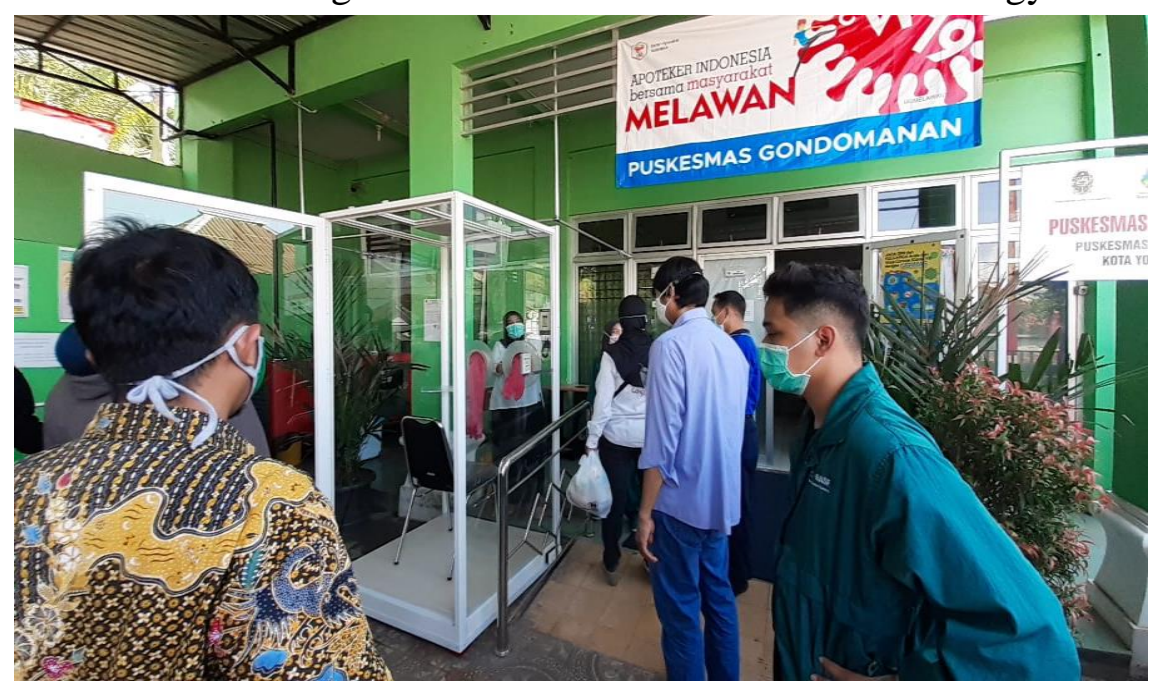

Gambar 5. Bilik Sampel Covid-19 yang Sudah Terpasang di Puskemas Gondomanan 


\section{B. Kalibrasi Sensor}

\section{B.1 Kalibrasi sensor suhu dan kelembaban}

DHT22 merupakan sensor yang dapat mengukur suhu dan kelembaban udara. Sebelum digunakan, sensor DHT22 dikalibrasi terlebih dahulu. Kalibrasi DHT22 dilakukan dengan melakukan perbandingan dengan HTC V.02 environment sebagai kalibrator. Hal ini dilakukan untuk mengetahui tingkat akurasi dari sensor DHT22. Sensor DHT22 dan HTC V.02 Environment dilakukan pengambilan data mulai dari pukul 05.50 sampai 17.30 pada sebuah tempat outdoor dengan memanfaatkan perubahan suhu dan kelembaban udara dari pagi hari sampai sore hari. Tabel 3 menunjukkan hasil perbandingan suhu dan kelembaban antara DHT22 dan HTC V.02 Environment. Dari pengukuran diperoleh hasil rerata perbedaan suhu sekitar $1.72 \%$ dan kelembaban sekitar $8.98 \%$ antara sensor DHT22 dengan kalibrator HTC V.02 Environment. Hasil ini menunjukkan bahwa output sensor DHT22 cukup akurat.

Tabel 3. Hasil perbandingan suhu dan kelembaban DHT22 dan HTC V.02 Environment

\begin{tabular}{|c|c|c|c|c|c|c|c|}
\hline \multirow{2}{*}{ No } & \multirow{2}{*}{ Jam } & \multicolumn{3}{|c|}{ Suhu $\left({ }^{\circ} \mathrm{C}\right)$} & \multicolumn{3}{|c|}{ Kelembaban (\%) } \\
\hline & & DHT22 & HTC & $\%$ Error & DHT22 & HTC & $\%$ Error \\
\hline 1 & 5.5 & 22.1 & 22.4 & 1.34 & 78 & 67 & 16.42 \\
\hline 2 & 6 & 21.6 & 21.8 & 0.92 & 80.2 & 69 & 16.23 \\
\hline 3 & 6.1 & 21.5 & 21.8 & 1.38 & 82.8 & 75 & 10.4 \\
\hline 4 & 6.2 & 22.1 & 23.1 & 4.33 & 71.2 & 72 & 1.11 \\
\hline 5 & 6.3 & 23.8 & 25.2 & 5.56 & 53.4 & 58 & 7.93 \\
\hline 6 & 6.4 & 23.3 & 23.8 & 2.1 & 57.9 & 57 & 1.58 \\
\hline 7 & 6.5 & 24.8 & 25.4 & 2.36 & 46.6 & 50 & 6.8 \\
\hline 8 & 7 & 24.6 & 25.2 & 2.38 & 47.9 & 49 & 2.24 \\
\hline 9 & 7.1 & 25.8 & 26.2 & 1.53 & 47.3 & 46 & 2.83 \\
\hline 10 & 7.2 & 26.6 & 27.4 & 2.92 & 42 & 43 & 2.33 \\
\hline 11 & 7.3 & 25.4 & 25.5 & 0.39 & 54.4 & 50 & 8.8 \\
\hline 12 & 7.4 & 26 & 26.6 & 2.26 & 51.8 & 55 & 5.82 \\
\hline 13 & 7.5 & 27.8 & 28.6 & 2.8 & 40.6 & 43 & 5.58 \\
\hline 14 & 8 & 28.1 & 28.6 & 1.75 & 38.8 & 41 & 5.37 \\
\hline 15 & 8.3 & 29.5 & 29.5 & 0 & 36.9 & 37 & 0.27 \\
\hline 16 & 8.4 & 30.2 & 30.8 & 1.95 & 34 & 36 & 5.56 \\
\hline 17 & 8.5 & 30.3 & 30.7 & 1.3 & 32.5 & 34 & 4.41 \\
\hline 18 & 9 & 30.5 & 30.9 & 1.29 & 33.5 & 34 & 1.47 \\
\hline 19 & 9.1 & 30.9 & 32 & 3.44 & 33.6 & 34 & 1.18 \\
\hline 20 & 9.2 & 31.1 & 32.5 & 4.31 & 35 & 31 & 12.9 \\
\hline 21 & 9.3 & 31.6 & 32 & 1.25 & 35.4 & 31 & 14.19 \\
\hline 22 & 9.4 & 31.2 & 31.8 & 1.89 & 34.9 & 30 & 16.33 \\
\hline 23 & 9.5 & 31.6 & 32 & 1.25 & 34.3 & 32 & 7.19 \\
\hline 24 & 10 & 32 & 32 & 0 & 35.8 & 32 & 11.88 \\
\hline 25 & 10.1 & 31.9 & 32.2 & 0.93 & 34.8 & 31 & 12.26 \\
\hline 26 & 10.2 & 32.2 & 32.5 & 0.92 & 37.9 & 32 & 18.44 \\
\hline 27 & 10.3 & 32 & 32.2 & 0.62 & 38 & 32 & 18.75 \\
\hline 28 & 10.4 & 32.3 & 32.2 & 0.31 & 37.2 & 33 & 12.73 \\
\hline 29 & 10.5 & 32.3 & 32.5 & 0.62 & 36.7 & 32 & 14.69 \\
\hline 30 & 11 & 32.1 & 32.2 & 0.31 & 37.1 & 32 & 15.94 \\
\hline
\end{tabular}




\begin{tabular}{cccccccc}
\hline & & \multicolumn{3}{c}{ Suhu $\left({ }^{\circ} \mathrm{C}\right)$} & \multicolumn{3}{c}{ Kelembaban (\%) } \\
\cline { 3 - 7 } No & Jam & DHT22 & HTC & \%Error & DHT22 & HTC & \%Error \\
\hline 31 & 12.35 & 32.4 & 32.8 & 1.22 & 39.3 & 35 & 12.29 \\
32 & 12.45 & 32.6 & 33.1 & 1.51 & 39.6 & 36 & 10 \\
33 & 12.55 & 32.5 & 33.1 & 1.81 & 39.7 & 36 & 10.28 \\
34 & 13.05 & 32.4 & 32.8 & 1.22 & 40.8 & 35 & 16.57 \\
35 & 16.4 & 29.7 & 30.2 & 1.66 & 58.4 & 54 & 8.15 \\
36 & 16.5 & 29.5 & 30 & 1.67 & 60 & 56 & 7.14 \\
37 & 17 & 29.2 & 29.8 & 2.01 & 62.2 & 57 & 9.12 \\
38 & 17.1 & 29 & 29.5 & 1.69 & 62.3 & 58 & 7.41 \\
39 & 17.2 & 28.6 & 29.1 & 1.72 & 64.3 & 59 & 8.98 \\
40 & 17.3 & 28.3 & 28.8 & 1.74 & 64.5 & 60 & 7.5 \\
\hline
\end{tabular}

\section{B.2 Kalibrasi sensor tekanan udara}

Kalibrasi sensor tekanan udara D6F-PH0505AD3 dilakukan dengan membandingkan keluarannya dengan magnehelic pressure gauges. Hasil perbandingan luaran sensor dan kalibrator ditunjukkan pada Tabel 4. Dari tabel tersebut bisa terlihat bahwa rerata error pembacaan sensor tekanan dengan kalibrator adalah sekitar $6.94 \%$. Ini menunjukkan bahwa sensor cukup akurat dan bisa digunakan untuk sistem monitoring.

Tabel 4. Hasil Perbandingan Tekanan Udara D6F-PH0505AD3 dan Magnehelic Pressure Gauges

\begin{tabular}{cccc}
\hline \multirow{2}{*}{ Percobaan Ke- } & Tekanan Udara (Pa) & Rata-rata \%Error & Standar Deviasi \\
\hline 1 & -4 & 16.511 & 0.37 \\
2 & -8 & 7.185 & 0.344 \\
3 & -12 & 4.905 & 0.388 \\
4 & -16 & 6.22 & 0.559 \\
5 & -20 & 4.596 & 0.697 \\
6 & -24 & 7.928 & 0.512 \\
7 & -28 & 1.229 & 0.277 \\
\hline
\end{tabular}

\section{Pengujian Sistem Monitoring Bilik Swab Secara Keseluruhan \\ C.1 Pengujian Monitoring Suhu}

Hasil dari monitoring suhu mengikuti prosedur pada subbab 3.D ditunjukkan pada Gambar 6. Dari gambar dapat dilihat pada kondisi 1 (pintu terbuka exhaust mati) dan kondisi 3 (pintu tertutup exhaust mati) suhu berada di titik yang paling tinggi yaitu $30{ }^{\circ} \mathrm{C}$ dan suhu terendah pada kondisi 4 (pintu tertutup exhaust nyala) yaitu $28.4^{\circ} \mathrm{C}$. Suhu terendah kedua ialah pada kondisi 2 (pintu terbuka exhaust nyala). Dari data tersebut dapat dilihat exhaust memiliki pengaruh penting dalam menurunkan suhu di dalam boks kalibrasi. 


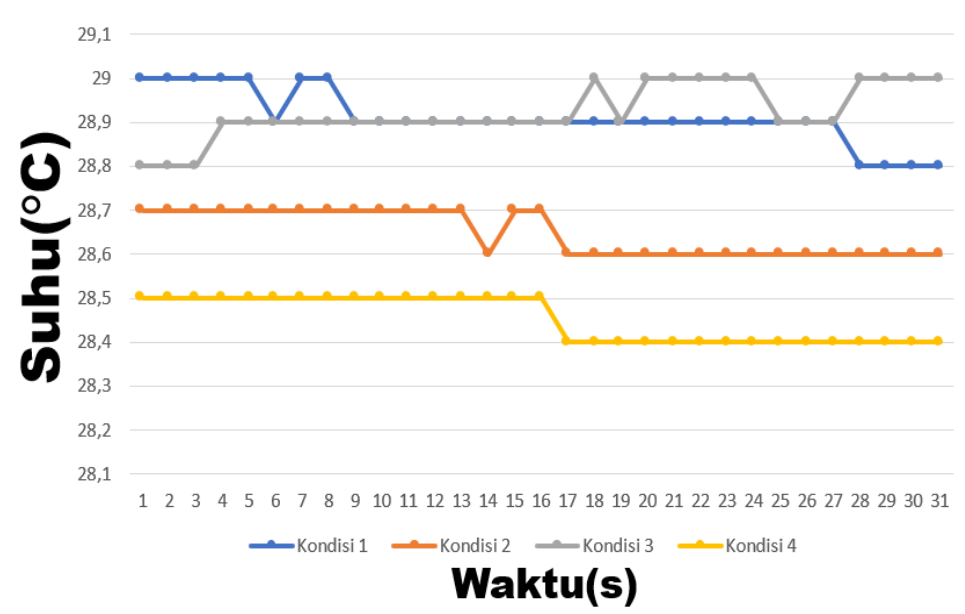

Gambar 6. Grafik suhu bilik swab pada empat kondisi kombinasi exhaust fan dan pintu

\section{C.2 Pengujian Monitoring Kelembaban}

Gambar 7 menunjukkan hasil monitoring kelembaban mengikuti prosedur di subbab 3.D. Grafik tersebut menunjukkan kelembaban udara yang rendah terdapat pada kondisi 1 (pintu terbuka exhaust mati) diantara $70 \%$ sampai $70.5 \%$. Pada kondisi 3 (pintu tertutup exhaust mati) terlihat kelembaban cenderung terus menurun. Kondisi 4 (pintu tertutup exhaust nyala) merupakan kondisi yang memiliki kelembaban tertinggi yaitu diatas $72 \%$. Kondisi 2 (pintu terbuka exhaust nyala) juga memiliki kondisi kelembaban yang tinggi dibawah kondisi ke 4 yaitu $72 \%$. Dari hal tersebut dapat dilihat bahwa exhaust mempengaruhi besarnya nilai kelembaban udara didalam mock-up bilik sampel Covid-19. Hal tersebut dikarenakan suhu berbanding terbalik dengan kelembaban. Semakin tinggi suhu maka kelembaban udaranya semakin mengecil karena terjadi pengembunan.

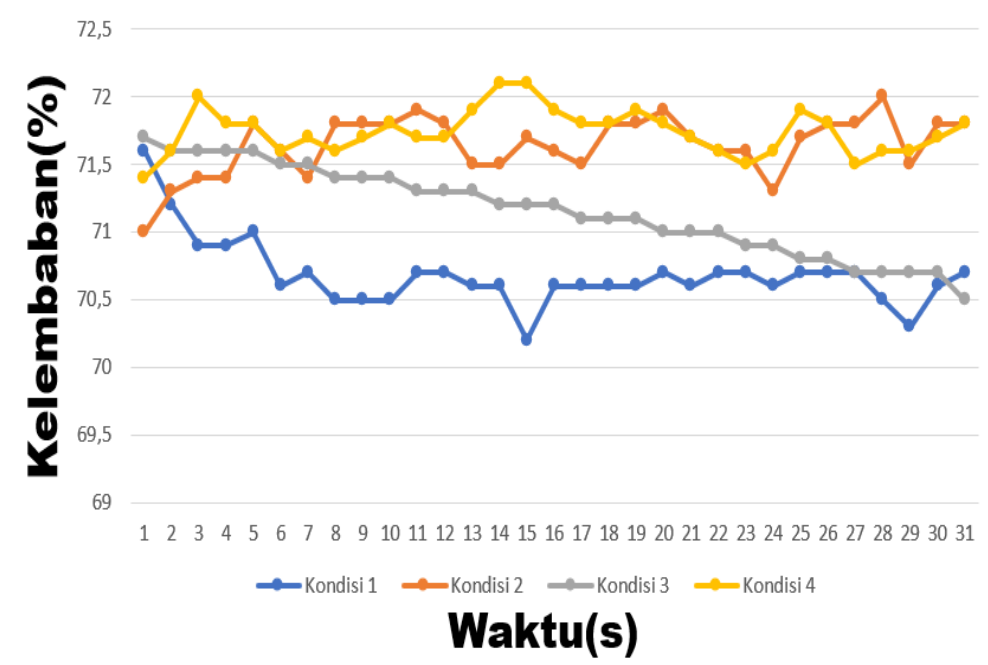

Gambar 7. Grafik kelembaban bilik swab pada empat kondisi kombinasi exhaust fan dan pintu

\section{C.3 Pengujian Monitoring Tekanan}

Hasil pengujian monitoring tekanan udara mengikuti prosedur pada subbab 3.D. ditunjukkan pada Gambar 8. dapat dilihat pada perbedaan tekanan udara tertinggi berada pada kondisi 4 (pintu tertutup exhaust nyala) yaitu diantara $-40 \mathrm{~Pa}$ sampai $-45 \mathrm{~Pa}$. Pada kondisi 1 (pintu terbuka exhaust mati) dan 2 (pintu terbuka exhaust nyala) dan pada kondisi 3 (pintu tertutup exhaust mati) perbedaan tekanan udara berada di sekitaran $0 \mathrm{~Pa}$. Dari 4 kondisi tersebut hanya pada saat pintu tertutup dan dan exhaust nyala yang nilai tekanan udara sesuai dengan standar ruangan bertekanan negatif yaitu 
perbedaan tidak lebih dari -2,5 Pa. Dari hal tersebut dapat dilihat bahwa udara keluar dan udara yang masuk mempengaruhi dalam pembuatan ruangan bertekanan negatif.

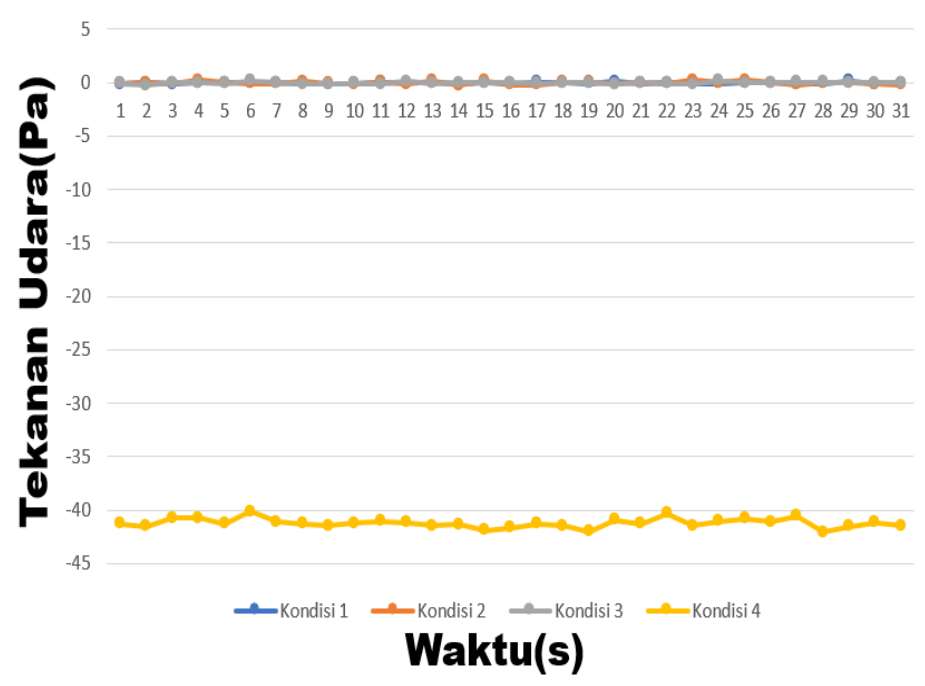

Gambar 8. Grafik tekanan udara bilik swab pada empat kondisi kombinasi exhaust fan dan pintu

\section{Kesimpulan}

Pada projek ini telah dibuat bilik tes swab Covid-19. Bilik tersebut dilengkapi sistem monitoring suhu, kelembaban, dan tekanan udara. Dari hasil pengujian, bilik tes swab terbukti telah berfungsi dengan baik. Sistem tekanan udara negatif bekerja sempurna. Selain itu, parameter suhu, kelembaban serta tekanan bisa dimonitor dengan mudah. Sistem peringatan apabila tekanan udara di bawah standar juga berfungsi dengan baik.

Bilik sampel telah diserahterimakan dan digunakan di Puskesmas Gondomanan Yogyakarta. Sistem monitoring dan peringatan dapat membantu pengguna mengetahui apakah bilik berfungsi dengan baik sesuai dengan desain demi keamanan tenaga medis, pasien, dan lingkungan sekitar. Desain bilik ini memiliki performa yang lebih baik dibandingkan dengan model bilik sampel yang telah ada sebelumnya.

\section{Ucapan Terima Kasih}

Penulis mengucapkan terimakasih kepada bapak/ibu dokter di Puskesmas Gondomanan dan bapak/ibu dokter bagian respirologi anak RS Sardjito yang telah memberikan masukan pada pengembangan bilik tes swab ini.

\section{Daftar Pustaka}

Choi, Han, C., Lee, J., Kim, S., Kim, I. B., Choi, S., Han, C., Lee, J., Si, K., \& Ib, K. (2020). Innovative Screening Tests For COVID-19 in South Korea. 7(2), 73-77.

Dwiatmo, C. (2020). Adaptasi Tata Ruang \& Tata Udara Ruang Isolasi RSUP Persahabatan di Masa Pandemi Covid-19. Komite PPI RSUP Persahabatan.

Fadillah, M. L. (2020). Prototipe Bilik Sampel Covid-19 Dan Sistem Monitornya. Universitas Islam Indonesia.

Gunardi, W. D. (2021). Pemeriksaan Diagnosis Laboratorium COVID-19: Keterbatasan dan Tantangannya Saat Ini. Jurnal Kedokteran Meditek, 27(2), 173-182. https://doi.org/10.36452/jkdoktmeditek.v27i2.2036 
Hairunisa, N., \& Amalia, H. (2020). Review : Penyakit virus corona baru 2019 ( COVID-19 ). Jurnal Biomedika Dan Kesehatan, 3(2), 90-100. https://doi.org/10.18051/JBiomedKes.2020.v3.90100

HIPPII PUSAT. (2019). Penatalaksaan Ruang Isolasi Airborne Transmission. Himpunan Perawat Pencegah dan PengendaliInfeksi Indonesia.

Kementerian Kesehatan. (2012). Pedoman Teknis Prasarana Sistem Tata Udara Pada Bangunan Rumah Sakit. In Kementerian Kesehatan - RI (pp. 1-87). Kementerian Kesehatan RI.

Mouser Electronics. (2021). Omron Electronics D6F-PH Differential Pressure Sensors. https://www.mouser.co.id/new/omron-electronics/Omron-D6F-PH/

Perdalin Kotapraja. (2017). Ruang Isolasi Tekanan Negatif. PERDALIN KOTAPRAJA. http://perdalinkotapraja.or.id/node/120

Saptadi, A. H. (2015). Perbandingan Akurasi Pengukuran Suhu dan Kelembaban Antara Sensor DHT11 dan DHT22 Studi Komparatif pada Platform ATMEL AVR dan Arduino. Jurnal Informatika,Telekomunikasi Dan Elektronika, 6(2). https://doi.org/10.20895/infotel.v6i2.73

Sarbani. (2020). Manajemen Tata Udara di Ruang Isolasi. https://rspmanguharjo.jatimprov.go.id/wp-content/uploads/2020/09/Tata-Udara-Pandemikirim.pdf

World Health Organization. (2007). Pencegahan dan pengendalian infeksi saluran pernapasan akut (ISPA) yang cenderung menjadi epidemi dan pandemi di fasilitas pelayanan kesehatan. In Pedoman Interim WHO. https://doi.org/10.37506/ijfmt.v14i4.12406

World Health Organization. (2020). Deteksi Antigen dalam Diagnosis Infeksi SARS-CoV-2 Menggunakan Imunoasai Cepat. https://www.who.int/docs/defaultsource/searo/indonesia/covid19/deteksi-antigen-dalam-diagnosis-infeksi-sars-cov-2menggunakan-imunoasai-cepat.pdf?sfvrsn=222f2be3_2 